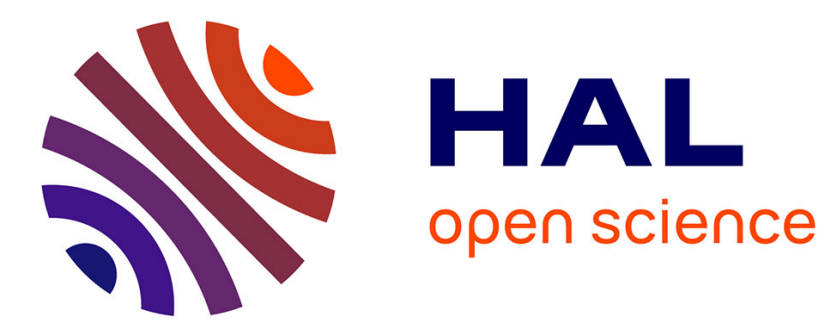

\title{
Cobalt-containing BEA zeolite for catalytic combustion of toluene
}

\author{
Anna Rokicińska, Marek Drozdek, Barbara Dudek, Barbara Gil, Piotr \\ Michorczyk, Dalil Brouri, Stanislaw Dzwigaj, Piotr Kuśtrowski
}

\section{- To cite this version:}

Anna Rokicińska, Marek Drozdek, Barbara Dudek, Barbara Gil, Piotr Michorczyk, et al.. Cobaltcontaining BEA zeolite for catalytic combustion of toluene. Applied Catalysis B: Environmental, 2017, 212, pp.59 - 67. 10.1016/j.apcatb.2017.04.067 . hal-01517429

\section{HAL Id: hal-01517429 \\ https://hal.sorbonne-universite.fr/hal-01517429}

Submitted on 3 May 2017

HAL is a multi-disciplinary open access archive for the deposit and dissemination of scientific research documents, whether they are published or not. The documents may come from teaching and research institutions in France or abroad, or from public or private research centers.
L'archive ouverte pluridisciplinaire HAL, est destinée au dépôt et à la diffusion de documents scientifiques de niveau recherche, publiés ou non, émanant des établissements d'enseignement et de recherche français ou étrangers, des laboratoires publics ou privés. 


\section{Cobalt-containing BEA zeolite for catalytic combustion of toluene}

Anna Rokicińska ${ }^{1}$, Marek Drozdek ${ }^{1}$, Barbara Dudek $^{1}$, Barbara Gil ${ }^{1}$, Piotr Michorczyk ${ }^{2}$, Dalil Brouri ${ }^{3}$, Stanislaw Dzwigaj ${ }^{3, *}$, Piotr Kuśtrowski ${ }^{1, *}$

${ }^{1}$ Department of Chemical Technology, Faculty of Chemistry, Jagiellonian University, Ingardena 3, 30-060 Kraków, Poland

${ }^{2}$ Institute of Organic Chemistry and Technology, Cracow University of Technology, Warszawska 24, 31-155 Kraków, Poland

${ }^{3}$ Sorbonne Universités, UPMC Univ Paris 06, CNRS, UMR 7197, Laboratoire de Réactivité de Surface, 4 place Jussieu, Case 168, F-75252, Paris, France

${ }^{*}$ Corresponding authors:

Piotr Kustrowski, E-mail: piotr.kustrowski@chemia.uj.edu.pl, Tel. +48-12-6632006

Stanislaw Dzwigaj, E-mail: stanislaw.dzwigaj@upmc.fr, Tel. +33144272113 
GRAPHICAL ABSTRACT
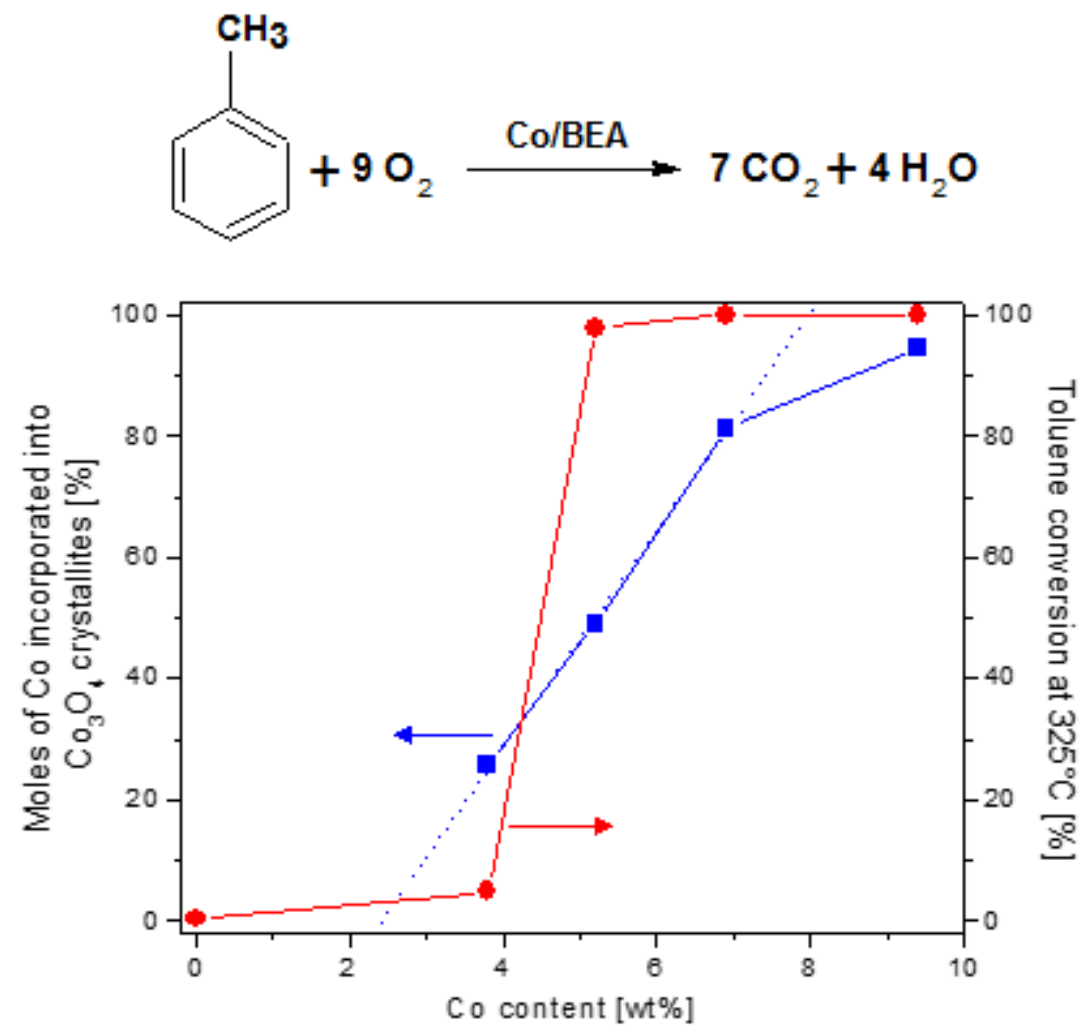

\section{Highlights}

- Controlled amounts of cobalt were homogeneously introduced in BEA structure.

- Various forms of Co species were identified in Co-containing BEA structure.

- After saturation of framework sites Co formed oxide clusters and crystallites.

- The presence of Lewis acid sites resulted in enhanced selectivity to $\mathrm{CO}$ and benzene.

- The highest activity showed Co-containing SiBEA with dominant contribution of $\mathrm{Co}_{3} \mathrm{O}_{4}$.

\section{Abstract}

Co-containing HAlBEA zeolite was obtained by conventional wet impregnation of HAlBEA zeolite with an aqueous $\mathrm{Co}\left(\mathrm{NO}_{3}\right)_{2} \cdot 6 \mathrm{H}_{2} \mathrm{O}$ solution, whereas Co-containing SiBEA zeolites were prepared by a two-step post-synthesis method. This approach consists of, in the first 
step, dealumination of parent BEA zeolite to obtain an aluminum-free SiBEA support and then, in the subsequent step, contact of the obtained material with an aqueous solution of cobalt nitrate. As shown by $\mathrm{X}$-ray diffraction and low-temperature $\mathrm{N}_{2}$ adsorption, the dealumination of BEA zeolite and introduction of cobalt ions did not involve destruction of zeolite structure, and only insignificant blocking of pore system was observed after introduction of high amounts of cobalt. Nevertheless, clear changes in acidity were found by FTIR of pre-adsorbed pyridine after dealumination of parent BEA zeolite and introduction of cobalt ions. The presence of Lewis acid sites resulted in enhanced selectivity to $\mathrm{CO}$ and benzene formed as by-products in the toluene combustion. Therefore, SiBEA zeolite was chosen as a support for an introduction of various amounts of Co into the zeolite structure (the intended Co contents of $3.0-9.0$ wt \%). Depended on the amount of the introduced Co, cobalt was incorporated into the framework of BEA zeolite as isolated mononuclear Co(II) species, small $\mathrm{Co}(\mathrm{II})$ oxide clusters and/or $\mathrm{Co}_{3} \mathrm{O}_{4}$ crystallites distributed in the whole zeolite structure. The chemical environment and dispersion of cobalt species were studied by transmission electron microscopy (TEM), FTIR of pre-adsorbed NO, UV-vis diffuse reflectance spectroscopy and X-ray photoelectron spectroscopy (XPS). Temperature-programmed reduction of hydrogen $\left(\mathrm{H}_{2}\right.$-TPR) was also performed to determine reducibility of the Cocontaining SiBEA zeolites. It was confirmed that siliceous SiBEA zeolite was the excellent support of $\mathrm{Co}_{3} \mathrm{O}_{4}$, which was in turn recognized as the main active phase in the total oxidation of toluene. The best catalytic performance was achieved over the catalysts containing at least $0.05 \mathrm{mmol}$ of $\mathrm{Co}$ in the form of $\mathrm{Co}_{3} \mathrm{O}_{4}$ per $1 \mathrm{~g}$ of $\mathrm{SiBEA}$ zeolite.

Keywords: BEA zeolite, $\mathrm{Co}_{3} \mathrm{O}_{4}$, volatile organic compounds, toluene, catalytic total oxidation

\section{Introduction}


Growing emission level of volatile organic compounds (VOCs), related to the development of human civilization, causes many environmental and human hazards including the formation of ground-level ozone and urban aerosol precursors, the appearance of odor and the negative health effects for animals and humans (such as cancer, throat irritation, respiratory issues or memory impairment) [1-4]. Therefore, strict regulations for reducing VOCs concentration in the environment have been established in many countries. Furthermore, great efforts have been made to find an effective, economically feasible method for the abatement of VOCs evolved from anthropogenic sources.

The catalytic total oxidation of organic pollutants, which is more selective (only $\mathrm{CO}_{2}$, $\mathrm{H}_{2} \mathrm{O}$ and other less harmful products are formed) and can be performed at much lower temperatures $\left(\mathrm{T}<500^{\circ} \mathrm{C}\right.$ results in energy saving and excluded formation of $\mathrm{NO}_{\mathrm{x}}$ during the combustion in air) than thermal oxidation, is considered as one of the most promising technologies to treat waste gas streams with relatively low concentration of unusable VOCs [5-8]. Noble metal-based materials (e.g. Pt [9-15] and Pd [16-21] dispersed on various supports, such as $\mathrm{Al}_{2} \mathrm{O}_{3}[6,9-10,12,14,17,19-20], \mathrm{ZrO}_{2}[6,19]$ or $\mathrm{TiO}_{2}$ [16-18]), are usually studied in a role of catalysts of the VOCs combustion. They exhibit very high catalytic activity at relatively low temperatures, but are expensive and prone to deactivation by sintering or poisoning. Alternatively, supported or unsupported transition and rare earth metal oxides can be used. Such catalysts are void of disadvantages typical of precious metalcontaining systems. However, significantly lower activities in the VOCs combustion are achieved in their presence. The most commonly studied metal oxide catalysts include Co- [5, 22-25], $\mathrm{Cu}-[5,22,26], \mathrm{Mn}-[5,22,25], \mathrm{Ce}-[5,12,16,26]$, and Fe-containing materials [21, 22]. It has been found that a suitable chosen support with controlled porosity favors high dispersion of active phase and enhanced activity in the total oxidation of VOCs [27-28]. From this point of view, zeolites can be expected as interesting supports of metal oxide species for 
the abatement of relatively small organic molecules, which can enter and migrate through channels present in the structure of these materials [13-15, 21-22, 29-30].

Beta (BEA) zeolite, produced in commercial scale as a high-silica zeolite, has a threedimensional structure with three perpendicular 12-ring channel systems characteristic of the three ordered polytypes (A, B and C) [31-34]. It possesses pores larger than those of ZSM-5 with 12 -memeberd ring openings $(0.75$ by $0.57 \mathrm{~nm}$ for linear and 0.65 by $0.56 \mathrm{~nm}$ for tortuous channels). BEA zeolite was tested as a support of catalytically active phases [35-39], including the total oxidation of VOCs [13-15, 20-21, 40]. In the latter case, a majority of research was done for noble-metal systems. Nevertheless, $\mathrm{MnO}_{2}$ was also used as transition metal oxide deposited on BEA zeolite for the toluene combustion [22]. The $\mathrm{MnO}_{2} / \mathrm{BEA}$ zeolite catalyst was significantly more active than unsupported and ZSM-5-supported $\mathrm{MnO}_{2}$, but exhibited higher $\mathrm{T}_{50}$ (temperature of $50 \%$ substrate conversion) than $\mathrm{MnO}_{2} /$ clinoptilolite. Among precious metals, Pt showed higher activity than Pd [13-15, 20-21, 40]. O'Malley and Hodnett showed that reactivity of VOCs in the total oxidation reaction on Pt/BEA zeolite was strongly depended on the strength of the weakest $\mathrm{C}-\mathrm{H}$ bond in the volatile organic compounds structure [40]. The reaction proceeds by initial rupture of such bond followed by subsequent steps that may involve free radical transformations. The stability of noble metal deposited on BEA zeolite in the VOCs combustion can be enhanced by using of partially dealuminated support, addition of co-promoters (e.g. Fe) or formation of hierarchical micromesoporous system $[15,21]$. Nevertheless, these catalysts are still characterized by relatively low stability.

On the other hand, cobalt-containing materials have been found to be very efficient catalysts of the total oxidation of VOCs $[5,41-44] . \mathrm{Co}_{3} \mathrm{O}_{4}$ was recognized to be the active phase, which after dispersion on the appropriate support brings about excellent catalytic performance. Therefore, we have decided to prepare series of Co-containing zeolite materials 
with cobalt introduced in the BEA zeolite by two-step post-synthesis method, developed earlier by Dzwigaj at al. for incorporation of vanadium in BEA zeolite [45-48], and investigate the influence of the cobalt state and acidity of zeolite support on the catalytic performance of the synthesized materials in the combustion of toluene. In the presented work, we demonstrate the collected catalytic results combined with the physicochemical characterization of samples, which defines their composition (X-ray fluorescence, XRF), structure (XRD, TEM), porosity (nitrogen adsorption), acidity (FTIR of adsorbed pyridine), reducibility (temperature-programmed reduction) and transition metal state (XPS, UV-vis-DR and FTIR of adsorbed NO).

\section{Experimental}

\subsection{Materials}

HAlBEA zeolite was prepared by calcination of parent tetraethylammonium BEA zeolite (TEABEA) with atomic $\mathrm{Si} / \mathrm{Al}$ ratio of 14 at $550{ }^{\circ} \mathrm{C}$ for $15 \mathrm{~h}$ in air, ion exchange of the asobtained material with $\mathrm{NH}_{4} \mathrm{NO}_{3}$ solution of $1 \cdot 10^{-1} \mathrm{~mol} \cdot \mathrm{L}^{-1}$ at $70^{\circ} \mathrm{C}$ for $3 \mathrm{~h}$ and then calcination at $500{ }^{\circ} \mathrm{C}$ for $3 \mathrm{~h}$ in air. Co-loaded HAlBEA zeolite was prepared by wet impregnation of HAlBEA zeolite with an aqueous solution of $\mathrm{Co}\left(\mathrm{NO}_{3}\right)_{2} \cdot 6 \mathrm{H}_{2} \mathrm{O}\left(11.1 \cdot 10^{-3}\right.$ $\mathrm{mol} \cdot \mathrm{L}^{-1}$ ) at room temperature and $\mathrm{pH}=3.5$. The cobalt containing catalyst, obtained after calcination at $500{ }^{\circ} \mathrm{C}$ for $3 \mathrm{~h}$ in air, was labeled HAlBEACo7.0.

For preparation of Co-containing SiBEA zeolites, TEABEA zeolite was dealuminated by a treatment with nitric acid solution $\left(13 \mathrm{~mol} \cdot \mathrm{L}^{-1}\right)$ at $80{ }^{\circ} \mathrm{C}$ for $4 \mathrm{~h}$, washed several times with distilled water and dried at $95{ }^{\circ} \mathrm{C}$ overnight. Then, the obtained material was contacted with an aqueous solution of cobalt nitrate $(1 \mathrm{~g}$ of zeolite in $200 \mathrm{~mL}$ of solution $)$ and stirred at $25^{\circ} \mathrm{C}$ for $24 \mathrm{~h}$. The concentration of the $\mathrm{Co}\left(\mathrm{NO}_{3}\right)_{2}$ solution varied from $5.1 \cdot 10^{-3}$ to $15.3 \cdot 10^{-3} \mathrm{~mol}$ • $\mathrm{L}^{-1}$. Subsequently, the suspension was transferred to an evaporator and stirred under vacuum 
of a water pump at $60{ }^{\circ} \mathrm{C}$ for $2 \mathrm{~h}$ until water was evaporated. The samples calcined at $500{ }^{\circ} \mathrm{C}$ for $3 \mathrm{~h}$ in air were labeled SiBEACo3.0, SiBEACo5.0, SiBEACo7.0 and SiBEACo9.0.

\subsection{Characterization}

Chemical analysis of all samples was performed by XRF using a Thermo Scientific ARL Quant'x spectrometer. Powder X-ray diffraction (XRD) patterns were recorded using a Bruker D2 Phaser diffractometer with CuK $\alpha$ radiation $(\lambda=1.54056 \AA)$. The diffractograms were collected in the $2 \theta$ range of $3-70^{\circ}$ with a scanning rate of $0.02^{\circ}$. All samples were examined in a powder form.

Textural properties of the materials were determined by low-temperature adsorption of nitrogen at $-196^{\circ} \mathrm{C}$ using a Micromeritics ASAP 2020 sorptometer. Before the measurements, samples were outgassed at $250^{\circ} \mathrm{C}$ for $5 \mathrm{~h}$ under vacuum.

Cobalt speciation and acidity were investigated by FTIR spectroscopy based on adsorption of NO and pyridine used as probe molecules. The samples were activated in the form of self-supporting wafers for $1 \mathrm{~h}$ at $450{ }^{\circ} \mathrm{C}$ prior to the adsorption of probe molecules at the following temperatures: $-100{ }^{\circ} \mathrm{C}$ for NO (Linde Gas Polska, $99.95 \%$ purified directly before use by freeze-and-thaw) and $170{ }^{\circ} \mathrm{C}$ for pyridine (POCh Gliwice, analytical grade). For NO adsorption the IR cell was cooled down to ca. $-100{ }^{\circ} \mathrm{C}$ using liquid nitrogen bath and measuring the temperature inside the cell. The spectra were recorded with a PerkinElmer Frontier spectrometer equipped with a DTGS detector and working with the spectral resolution of $2 \mathrm{~cm}^{-1}$. All spectra presented in this work were normalized to the standard 10 mg pellet (density of $3.2 \mathrm{mg} \mathrm{cm}^{-2}$ ) and the accuracy of normalization was verified by comparing the overtones for all samples. The concentrations of Lewis (LAS) and Brønsted (BAS) acid sites were calculated using previously reported absorption coefficients [49] $\varepsilon($ LAS and Py-Co $)=0.165 \mathrm{~cm}^{2} \mu \mathrm{mol}^{-1}$ and $\varepsilon(\mathrm{BAS})=0.044 \mathrm{~cm}^{2} \mu \mathrm{mol}^{-1}$ - and the intensities 
of the corresponding pyridine maxima after pyridine desorption at $170{ }^{\circ} \mathrm{C}$ to ensure complete removal of weakly adsorbed species.

Temperature-programmed reduction with hydrogen $\left(\mathrm{H}_{2}\right.$-TPR) was carried using purified mixture of $\mathrm{N}_{2} / \mathrm{H}_{2}(95 / 5$ vol. \%, Air Liquide) served as a simultaneous carrier and reducing gas at a total flow rate of $40 \mathrm{~mL} \cdot \mathrm{min}^{-1}$. Before an experiment, a catalyst sample (40 $\left.\mathrm{mg}\right)$ was preheated in a dry He stream at $350{ }^{\circ} \mathrm{C}$ for $30 \mathrm{~min}$. After that, the sample was cooled down to room temperature and the TPR experiment was initialized. The sample was heated at a rate of $10{ }^{\circ} \mathrm{C} \cdot \min ^{-1}$ to the final temperature of $900^{\circ} \mathrm{C}$. The $\mathrm{H}_{2}$ consumption was measured by a thermal conductivity detector against $\mathrm{NiO}$ (99.999\%, Aldrich) used for calibration of $\mathrm{H}_{2}$ consumption.

UV-Vis diffuse reflectance spectra were collected using a Thermo Scientific Evolution 220 spectrometer in the range of $200-1000 \mathrm{~nm}$ with resolution of $1 \mathrm{~nm}$ collecting 60 scans per minute. Samples were diluted to about $4 \%$ by weight in $\mathrm{KBr}$ (analytical grade).

Transmission electron microscopy (TEM) was performed on a JEOL JEM 2011 microscope of the Plateforme de l'Intstut des Matériaux de Paris (Sorbonne Université, UPMC Univ Paris 06), operating at $200 \mathrm{kV}$, equipped with X-ray energy dispersive spectroscopy (XEDS) for chemical analysis. Samples were prepared by dispersing the powder ultrasonically in ethanol and depositing a drop on the carbon film of a copper grid.

X-ray photoelectron spectroscopy (XPS) measurements were conducted using a Prevac photoelectron spectrometer equipped with a monochromatized aluminium source $\mathrm{AlK} \alpha$ $(\mathrm{E}=1486.6 \mathrm{eV})$ and a hemispherical VG SCIENTA R3000 analyzer. Samples were introduced through a load lock into an ultrahigh vacuum analytical chamber with the base pressure of $5 \cdot 10^{-9}$ mbar. To compensate the charge on the surface of nonconductive samples, a low energy electron flood gun (FS40A-PS) was used. The scale of the binding energy value 
was adjusted by reference of the $\mathrm{Si} 2 \mathrm{p}$ peak at $103.0 \mathrm{eV}$. The spectra were fitted with Casa XPS software.

\subsection{Catalytic activity}

The zeolite materials were tested as catalysts in the total oxidation of toluene. $0.1 \mathrm{~g}$ of a catalyst, comminuted and sieved to a particle size of $160-315 \mu \mathrm{m}$, was placed in a central position of quartz flow microreactor on a quartz wool plug and outgassed, prior to a catalytic run, at $500{ }^{\circ} \mathrm{C}$ for $30 \mathrm{~min}$ in flowing air $\left(100 \mathrm{~mL} \cdot \mathrm{min}^{-1}\right)$. Then, the reactor was cooled down to $200{ }^{\circ} \mathrm{C}$ and toluene dosing started by passing air through a saturator (kept at $-7.5^{\circ} \mathrm{C}$ ) to achieve the toluene vapor concentration of $1000 \mathrm{ppm}$ in the reaction mixture. The catalytic tests were carried out at $200,250,275,300,325,350,400,450$ and $500{ }^{\circ} \mathrm{C}$. The reactor was kept at each temperature (reached at a heating rate of $10^{\circ} \mathrm{C} \cdot \mathrm{min}^{-1}$ ) for $80 \mathrm{~min}$ with three 25 minute lasting analyses of reaction products conducted using a Bruker 450-GC gas chromatograph equipped with three columns (Molecular Sieve 5A for separation of $\mathrm{O}_{2}, \mathrm{~N}_{2}$ and $\mathrm{CO}$, Porapak $\mathrm{S}$ for separation of $\mathrm{CH}_{4}, \mathrm{CO}_{2}$ and $\mathrm{H}_{2} \mathrm{O}$, and Chromosorb WAW-DMCS for separation of aromatic compounds), a thermal conductivity detector, two flame ionization detectors as well as a methaniser. Each catalytic test was repeated two times for checking reproducibility.

\section{Results and discussion}

\subsection{Effect of zeolite acidity}

Two different BEA zeolites were used as supports of Co-containing active phase protonated zeolite (HAlBEA) with the $\mathrm{Si} / \mathrm{Al}$ molar ratio of 14 and dealuminated one (SiBEA) with the Si/Al molar ratio > 1500. As shown in Fig. 1, the XRD patterns of both supports exhibit the presence of diffraction lines typical of the polymorphic BEA zeolite structure [50]. 
After the introduction of comparable amount of cobalt (6.7 - $6.9 \mathrm{wt} \%)$ nto both BEA zeolite supports (cf. Table 1), apart from the reflections attributed to the zeolite structure, the (311), (511) and (440) diffraction lines corresponding to the $\mathrm{Co}_{3} \mathrm{O}_{4}$ phase appear at $36.8^{\circ}, 59.4^{\circ}$ and $65.3^{\circ}$, respectively. The $\mathrm{Co}_{3} \mathrm{O}_{4}$ crystallite size of $17-20 \mathrm{~nm}$, estimated using the Scherrer equation (based on the (311) peak broadening), is similar for both studied Co-containing zeolite materials. The high background and a slight decrease in the intensity of diffraction lines, identified for the Co-rich samples, could be explained by fluorescence effect produced by copper X-rays.

Porosity of the materials was studied by nitrogen adsorption. The collected results are presented in Fig. 2 and Table 1. The $\mathrm{N}_{2}$ adsorption isotherms for HAlBEA and SiBEA have a shape categorized to type I - type IV, characteristic of micro-mesoporous materials, according to the IUPAC classification. It should be noted that after dealumination additional mesopores appeared in the zeolite structure. On the other hand, the introduction of Co-containing species resulted in a partial blocking of pore system. For both Co-containing BEA zeolites lower surface areas (determined by BET ( $\left.\mathrm{S}_{\mathrm{BET}}\right)$, Langmuir ( $\left.\mathrm{S}_{\text {Langmuir }}\right)$ and t-plot models), micropore volumes $\left(\mathrm{V}_{\text {micro }}\right.$ determined by t-plot method), mesopore volumes $\left(\mathrm{V}_{\text {meso }}\right.$ determined by BJH method applying the desorption branches of the isotherms) and total pore volumes ( $\mathrm{V}_{\text {total }}$ determined by single point method) are observed compared these determined for the parent supports. The HAIBEACo7.0 and SiBEACo7.0 materials are characterized by similar surface area and pore volume. Therefore, taking into account the above mentioned results of chemical analysis and calculation of $\mathrm{Co}_{3} \mathrm{O}_{4}$ crystallite size, it should be expected that in both catalysts very similar dispersion of $\mathrm{Co}_{3} \mathrm{O}_{4}$ species was achieved.

Adsorption of pyridine was performed to test the acidity of the samples. The determined concentrations of acid sites are given in Table 1. Only the HAlBEA-based materials contain Brønsted acid sites (the absorption band at $1545 \mathrm{~cm}^{-1}$ ). For these zeolites also Lewis acid sites 
originating from framework and extra-framework $\mathrm{Al}$ are present, manifested by the IR maximum at $1455 \mathrm{~cm}^{-1}$. Dealumination of BEA zeolite results in a complete disappearance of both types of acid sites. The cobalt-containing SiBEA samples have neither Brønsted nor Altype Lewis acidity. The IR maxima observed at $1449 \mathrm{~cm}^{-1}$ for these materials are characteristic of pyridine bonded to accessible cobalt ions. The number of such cobalt ions, able to bond pyridine, is practically constant when the amount of Co is higher than 5 wt $\%$ (Table 1).

The catalytic activity of the HAIBEA and SiBEA zeolites before and after modification with 7 wt $\%$ of Co was examined in the toluene combustion. The collected results are shown in Fig. 3. The main products of the studied reaction were $\mathrm{CO}_{2}$ and $\mathrm{H}_{2} \mathrm{O}$. However, the formation of $\mathrm{CO}$ and small amounts of benzene was also detected. The Co-free zeolite samples are rather poorly active and start to catalyze the toluene transformation above $325{ }^{\circ} \mathrm{C}$. Significantly higher toluene conversions are achieved in the presence of the HAlBEA sample, but it should be noted that this material is less selective in the total oxidation of the selected aromatic hydrocarbon. Some amounts of $\mathrm{CO}$, which appeared above $400{ }^{\circ} \mathrm{C}$ for HAlBEA, are probably due to the presence in this sample of iron impurities evidenced in HAlBEA zeolite structure in our earlier report [51], responsible for partial oxidation of toluene into CO. Higher quantities of benzene are also formed in this case. The catalytic performance of zeolite support changes drastically after the introduction of Co. Both studied samples HAlBEACo7.0 and SiBEACo7.0 - exhibit very similar activity and selectivity profiles. The reaction begins at about $300{ }^{\circ} \mathrm{C}$ (conversions of $1.7-2.0 \%$ ), but a further increase in the reaction temperature to $325^{\circ} \mathrm{C}$ causes that the total conversion of toluene is achieved. The traces of $\mathrm{CO}$ (yield below $0.1 \%$ ) and benzene (yield below $0.4 \%$ ) are produced only in the case of the HAlBEACo7.0 catalyst. Taking into account the collected results it should be concluded that the elimination of acid sites seems to be a good solution for improving the 
reaction selectivity to $\mathrm{CO}_{2}$ and $\mathrm{H}_{2} \mathrm{O}$. Therefore, the further studies were performed for the series of SiBEA zeolites containing various Co contents.

\subsection{Effect of cobalt content}

The applied two-step post-synthesis procedure allowed to obtain the SiBEA-based zeolite samples with the Co contents ranging from 3.8 to $9.4 \mathrm{wt} \%$, which are close to the intended ones (cf. Table 1). Furthermore, the introduction of high amounts of Co into zeolite structure did not destroy the zeolite structure being still crystalline as is shown in the XRD patterns presented in Fig. 1. The decreasing intensities of diffraction lines observed for the Cocontaining BEA zeolite samples should be attributed to the above discussed fluorescence effect. The reflections related to the $\mathrm{Co}_{3} \mathrm{O}_{4}$ phase become more pronounced at the raising $\mathrm{Co}$ content. On the other hand, the appearance of the spinel crystallites results in a partial blocking of pore system, mainly mesopores are affected (Table 1 and Fig. 2). However, even for the sample with the highest Co content, the decrease in the textural parameters (surface area and pore volume) is not higher than $30 \%$ compared to the unmodified SiBEA support. This observation can suggest that the $\mathrm{Co}_{3} \mathrm{O}_{4}$ nanoparticles are formed in the voids between the zeolite grains, especially at higher the Co loadings.

TEM observations of the Co-loaded SiBEA zeolites pointed out the presence of two kinds of Co species detected by XEDS. As shown in Fig. 4A for SiBEACo5.0, the extra-framework Co species consisting of oxide with particle size around $20 \mathrm{~nm}$ and the framework Co species are identified. The extra-framework Co species were attributed by HRTEM to $\mathrm{Co}_{3} \mathrm{O}_{4}$ oxide (Fig. 4B). Inter-reticular distance of $4.6 \AA$ measured on the HRTEM micrograph corresponds to the [111] plans of $\mathrm{Co}_{3} \mathrm{O}_{4}$. The presence of the framework Co species was demonstrated by combining HRTEM and XEDS (Fig. 4C). Indeed, we observe Co signature in the XEDS spectra on zeolite grains with no nanoparticle observable. This can be explained by Co species 
present in the zeolite framework. Similar results were collected for the SiBEA samples with other Co contents, and more extra-framework Co species with higher particle size (even > 50 nm for CoSiBEACo9.0) appear at increasing Co loading.

In order to identify the nature of the surface species, the FTIR spectra of adsorbed NO were recorded for all cobalt-containing SiBEA zeolites. Fig. 5 shows the spectra recorded for the samples after NO adsorption and subsequent desorption at $-100{ }^{\circ} \mathrm{C}$. For all the samples the same bands appear. Two pairs of bands, characteristic of $\mathrm{Co}^{2+}(\mathrm{NO})_{2}$ dinitrosyls are present, the ones with maxima at $1813+1895 \mathrm{~cm}^{-1}$ are formed on isolated framework Co(II) species, while the second pair with maxima at $1885+1796 \mathrm{~cm}^{-1}$ are formed on the small Co(II) oxide clusters. In neither sample NO is bonded to the Co(III) species that is explicable considering poor interaction between the applied probes molecule and the surface of $\mathrm{Co}_{3} \mathrm{O}_{4}$ crystallites. Therefore, taking into account the similar intensities of the measured bands for all the Cocontaining BEA samples, it should be concluded that the SiBEA framework is saturated by isolated and clustered Co(II) species already for SiBEACo3.0. The further addition of cobalt results in its aggregation and the formation of $\mathrm{Co}_{3} \mathrm{O}_{4}$ crystallites.

UV-Vis diffuse reflectance spectroscopy provides some additional information on the chemical environment of cobalt species. The recorded spectra of the SiBEA zeolite and the samples containing various amounts of Co are presented in Fig. 6. For all the studied Comodified materials, the absorption band related to charge transfer transition between oxygen and cobalt in pseudo-tetrahedral and/or octahedral $\mathrm{Co}(\mathrm{II})$ is observed at about $305 \mathrm{~nm}$. Moreover, the bands attributed to isolated pseudo-tetrahedral $\mathrm{Co}$ (II) (band at $\sim 650 \mathrm{~nm}$ ) and octahedral $\mathrm{Co}$ (II) (band at $\sim 510 \mathrm{~nm}$ ) can be distinguished, as previously reported for Cocontaining BEA [52]. They are difficult for identification due to significant increase in the intensities of bands corresponding to the presence of increasing amounts of $\mathrm{Co}_{3} \mathrm{O}_{4}$. The band at $415 \mathrm{~nm}$ can be assigned to octahedrally coordinated $\mathrm{Co}(\mathrm{III})$ in the well-ordered spinel 
species, whereas the broad band above $700 \mathrm{~nm}$ to the electronic ligand-field ${ }^{4} \mathrm{~A}_{2}(\mathrm{~F}) \rightarrow{ }^{4} \mathrm{~T}_{1}(\mathrm{P})$ transition in pseudo-tetrahedral Co(II) species. Very similar UV-vis-DR spectra were collected for $\mathrm{Co}_{3} \mathrm{O}_{4}$ crystallites dispersed on the surface of mesoporous silicas (MCM-41 and SBA-15) [53].

The surface composition of the SiBEA series was studied by X-ray photoelectron spectroscopy. The obtained results show that $\mathrm{Si}, \mathrm{Co}$ and $\mathrm{O}$ are the main elements present on the surface of the samples. Moreover, traces of $\mathrm{C}$ and $\mathrm{Al}$ are detected. Fig. 7 demonstrates the Co $2 \mathrm{p}$ spectra. The Co $2 \mathrm{p}_{3 / 2}$ peak was deconvoluted into two components (with binding energies shown in Table 2), which are attributed to the presence of $\mathrm{Co}^{3+}$ and $\mathrm{Co}^{2+}$ species, respectively. The introduction of higher amounts of cobalt results in a gradual shift of the $\mathrm{Co}^{3+}$ component to lower values of binding energy. Additionally, the spin-orbit splitting (Co $2 \mathrm{p}_{1 / 2-3 / 2}$ ) becomes smaller with raising Co loading and reaches finally the value of $15.5 \mathrm{eV}$ for the SiBEACo9.0 sample. These effects confirm the appearance of Co(III) species incorporated into the $\mathrm{Co}_{3} \mathrm{O}_{4}$ phase and are in good agreement with the above discussed results of XRD and UV-vis diffuse reflectance measurements.

The analysis of the chemical composition determined by XPS (Table 2) brings a surprising conclusion. Keeping in mind the bulk composition measured by XRF, someone could expect that the content of Co measured by XPS should increase from SiBEACo3.0 to SiBEACo9.0. However, all the studied samples exhibit similar amounts of Co (2.4 - 3.7 at. \%) and the $\mathrm{Co}^{3+} / \mathrm{Co}^{2+}$ molar ratio (Table 2). It means that cobalt introduced into the SiBEA zeolite support during the post-synthesis preparation was mainly incorporated into the framework of zeolite as $\mathrm{Co}(\mathrm{II})$ species and formed $\mathrm{Co}_{3} \mathrm{O}_{4}$ nanocrystallites in zeolite channels and interparticle voids. The appearance of $\mathrm{Co}_{3} \mathrm{O}_{4}$ nanocrystallites involves the reduced porosity revealed by the $\mathrm{N}_{2}$ adsorption measurements. 
In order to estimate reducibility of the Co-loaded SiBEA catalysts, $\mathrm{H}_{2}$-TPR measurements were conducted. The collected $\mathrm{H}_{2}$-TPR profiles are shown in Fig. 8. In all cases a low temperature reduction peak located at $370-390{ }^{\circ} \mathrm{C}$ with shoulders and a second high temperature reduction peak ca. $715-740{ }^{\circ} \mathrm{C}$ appear. The reduction process starts at relatively low temperature, depending on the Co content. This temperature is the highest for the SiBEACo3.0 sample (about $260{ }^{\circ} \mathrm{C}$ ) and shifts to lower values after the addition of higher amounts of Co (finally to about $220{ }^{\circ} \mathrm{C}$ for SiBEACo9.0). The increasing Co content results also in the enhanced intensities of low temperature reduction peak. Both position and complex nature of this maximum, with shoulders, suggest that the observed phenomena corresponds to the reduction of $\mathrm{Co}_{3} \mathrm{O}_{4}$ particles. As it has been described in the literature, $\mathrm{Co}_{3} \mathrm{O}_{4}$ is reduced at similar temperature range as found in the case of the studied samples and its reduction process proceeds in two crucial steps: (i) $\mathrm{Co}_{3} \mathrm{O}_{4}$ to $\mathrm{CoO}$, and (ii) $\mathrm{CoO}$ to $\mathrm{Co}[54,55]$. In the low temperature range no reduction of isolated pseudo-tetrahedral $\mathrm{Co}$ (II) species present in the framework of BEA zeolite should be expected because of significantly higher temperatures are needed to reduce such species as has been reported by Chalupka et al. [52]. Our TPR results are in agreement with this literature data. The high temperature peaks, which can be assigned to reduction of $\mathrm{CoO}$ to $\mathrm{Co}$, appears above $700{ }^{\circ} \mathrm{C}$. Therefore, the determined low temperature reduction effect can be used to calculate the contribution of Co present in relatively easily reducible form (mainly $\mathrm{Co}_{3} \mathrm{O}_{4}$ ) according to the following equation:

$$
\begin{aligned}
& \% \text { of Co present in } \mathrm{Co}_{3} \mathrm{O}_{4} \text { form } \\
& \qquad=\frac{\frac{3}{4} \text { of } \mathrm{H}_{2} \text { amount consumed in TPR }\left[\frac{\mathrm{mmol}}{g_{\text {catalyst }}}\right]}{\text { content of Co determined by XRF }\left[\frac{m m o l}{g_{\text {catalyst }}}\right]} \times 100 \%
\end{aligned}
$$

The obtained results are shown in the inset in Fig. 8. Obviously, the increase in the amount of added Co causes that the spinel phase becomes the preferable form of Co introduction. Furthermore, extrapolation of the illustrated curve to $y=0$ suggests that the formation of $\mathrm{Co}_{3} \mathrm{O}_{4}$ should be expected from the content of Co somewhat higher than $3 \mathrm{wt} \%$. Below this 
value Co could be incorporated by the applied post-synthesis method exclusively in the form of isolated mononuclear Co(II) framework species.

Finally, the SiBEA-based materials with the various Co contents were tested as catalysts in the total oxidation of toluene. The toluene conversions achieved over the studied catalysts are illustrated in Fig. 9. As has been discussed previously, for the Co-containing SiBEA zeolites very high selectivity to $\mathrm{CO}_{2}$ are observed. No $\mathrm{CO}$ and very small traces of benzene (yield below $1 \%$ ), produced only at temperatures lower than $325^{\circ} \mathrm{C}$, are formed. We can find a clear effect of the Co content on the catalytic activity, which is more pronounced in the results of catalytic tests performed isothermally at $320{ }^{\circ} \mathrm{C}$ for $24 \mathrm{~h}$ (Fig. 10). Higher Co content gives higher toluene conversions. At the beginning of the reaction at $320{ }^{\circ} \mathrm{C}$, conversion of $1.8 \%$ is achieved over SiBEACo3.0, $19.1 \%$ for SiBEACo5.0, $82.0 \%$ for SiBEACo7.0 and $85.6 \%$ for SiBEACo9.0. On the other hand, as confirmed by these isothermal runs, the synthesized zeolite catalysts show high stability without noticeable deactivation in the toluene combustion during a 1 day period. Obviously, the content of $\mathrm{Co}_{3} \mathrm{O}_{4}$, which was recognized as the main active phase in the studied materials, influences the catalytic activity (Fig. 11). The catalytic performance is significantly enhanced up to the loading of about $0.05 \mathrm{mmol}$ of $\mathrm{Co}$ in the form of $\mathrm{Co}_{3} \mathrm{O}_{4}$ per $1 \mathrm{~g}$ of BEA zeolite. This effect is clearly demonstrated by turnover frequency (TOF) calculated as a number of moles of toluene consumed per second related to a number of moles of Co in a sample (Fig. 11). However, it should be kept in mind that the determined values of TOF are underestimated, especially in the catalysts with the higher Co contents, due to the presence of 3D spinel crystallites and relatively low dispersion of active phase. A similar inconvenience in the determination of TOF parameter was earlier reported by Papaefthimiou et al. [56] for $\gamma-\mathrm{Al}_{2} \mathrm{O}_{3}$-supported Cocontaining catalysts in the total oxidation of benzene, butanol and ethyl acetate. 
The toluene conversion over the developed materials is lower compared to those achieved in the presence of noble metal-containing BEA zeolites, previously described in the literature [13-15, 20]. The Pt-loaded BEA zeolites showed $\mathrm{T}_{50}$ even below $200{ }^{\circ} \mathrm{C}$ under conditions similar to those used in the present work. The application of transition metal-based active phase usually results in significantly lower catalytic activity. Nevertheless, the Co-modified BEA samples, studied here in the toluene combustion, appeared to be very promising among other transition metal-containing zeolite catalysts. Their activity is noticeably higher compared to $\mathrm{Cu}-$, Fe- and Mn-containing zeolites (Y, ZSM-5 and clinoptilolite) which gave the similar conversion of toluene at higher temperatures (even in the presence of higher amount of catalyst and lower content of toluene in the feed) [30,57].

The good dispersion of the $\mathrm{Co}_{3} \mathrm{O}_{4}$ spinel crystallites in the SiBEA zeolite provides easy reducibility of this phase, which provides lattice oxygen for the oxidation of aromatic hydrocarbon molecules. The reduced oxide phase is subsequently re-oxidized by molecular $\mathrm{O}_{2}$. The Mars-van Krevelen mechanism was previously confirmed for the combustion of toluene over the $\mathrm{Co}_{3} \mathrm{O}_{4}$-pillared clays [41].

\section{Conclusions}

The applied two-step post-synthesis procedure allowed us to effectively dealuminate the BEA zeolite and introduce the desirable amounts of Co without a noticeable destruction of the zeolite structure. However, dealumination resulted in the complete disappearance of Brønsted and Lewis acid sites. Dealuminated BEA zeolite appeared a more effective support of Cocontaining active phase due to higher selectivity to the products of total oxidation of toluene. On the other hand, isolated mononuclear Co(II) species, dominating in the samples with the low cobalt content, were less active in the studied process than $\operatorname{Co}($ II) oxide clusters and $\mathrm{Co}_{3} \mathrm{O}_{4}$ crystallites formed at the higher Co loadings. $\mathrm{Co}_{3} \mathrm{O}_{4}$ spinel was identified as the main 
active phase in the toluene combustion which proceeded according the Mars-van Krevelen mechanism. It was proven that the BEA zeolite support provided a suitable surface and pore system for high dispersion of active phase and accessibility of reactant molecules.

\section{Acknowledgment}

The research was carried out with the equipment purchased thanks to the financial support of the European Regional Development Fund in the framework of the Polish Innovation Economy Operational Program (contract No. POIG.02.01.00-12-023/08).

\section{References}

[1] C.Y. Lu, M.Y. Wey, L.I. Chen, Appl. Catal., A 325 (2007) 163-174.

[2] M. Amann, M. Lutz, J. Hazard. Mater. 78 (2000) 41-62.

[3] H. Guo, S.C. Lee, L.Y. Chan, W.M. Li, Environ. Res. 94 (2004) 57-66.

[4] A.P. Jones, Atmos. Environ. 33 (1999) 4535-4564.

[5] M.S. Kamal, S.A. Razzak, M.M. Hossain, Atmos. Environ. 140 (2016) 117-134.

[6] L.F. Liotta, Appl. Catal. B 100 (2010) 403-413.

[7] S. Scire, L.F. Liotta, Appl. Catal. B 125 (2012) 222-246.

[8] W.B. Li, J.X. Wang, H. Gong, Catal. Today 148 (2009) 81-87.

[9] J. Li, Y. Feng, S. Mo, H. Liu, Y. Chen, J. Yang, Part. Part. Syst. Charact. 33 (2016) 620627.

[10] Z. Abbasi, M. Haghighi, E. Fatehifar, S. Saedy, J. Hazard. Mater. 186 (2011) 1445-1454.

[11] H.J. Joung, J.H. Kim, J.S. Oh, D.W. You, H.O. Park, K.W. Jung, Appl. Surf. Sci. 290 (2014) 267-273.

[12] H.J. Sedjame, C. Fontaine, G. Lafaye, J. Barbier Jr, Appl. Catal. B 144 (2014) 233-242.

[13] C. Chen, Q. Wu, F. Chen, L. Zhang, S. Pan, C. Bian, X. Zheng, X. Meng, F.S. Xiao, J. Mater. Chem. A 3 (2015) 5556-5562. 
[14] Y. Takamitsu, S. Yoshida, W. Kobayashi, H. Ogawa, T. Sano, J. Environ. Sci. Health, Part A: Environ. Sci. Eng. 48 (2013) 667-674.

[15] C. Chen, J. Zhu, F. Chen, X. Meng, X. Zheng, X. Gao, F.S. Xiao, Appl. Catal. B 140-141 (2013) 199-205.

[16] Y.W. Chen, D.S. Lee, J. Nanosci. Nanotechnol. 13 (2013) 2171-2178.

[17] J.B. Kim, J.I. Park, H.S. Kim, Y.J. Yoo, J. Ind. Eng. Chem. 18 (2012) 425-428.

[18] V.P. Santos, S.A.C. Carabineiro, P.B. Tavares, M.F.R. Pereira, J.J.M. Orfao, J.L. Figueiredo, Appl. Catal. B 99 (2010) 198-205.

[19] K. Okumura, T. Kobayashi, H. Tanaka, M. Niwa, Appl. Catal. B 44 (2003) 325-331.

[20] Z. Zhang, L. Xu, Z. Wang, Y. Xu, Y. Chen, J. Nat. Gas Chem. 19 (2010) 417-421.

[21] J. Jacquemin, S. Siffer, J.F. Lamonier, E. Zhilinskaya, A. Aboukais, Stud. Surf. Sci. Catal. 142 (2002) 699-706.

[22] G.S.P. Soylu, Z. Ozcelik, I. Boz, Chem. Eng. J. 162 (2010) 380-387.

[23] S. Deng, X. Liu, N. Chen, D. Deng, X. Xiao, Y. Wang, Sens. Actuators, B 233 (2016) 615-623.

[24] B. Solsona, T.E. Davies, T. Garcia, I. Vazquez, A. Dejoz, S.H. Taylor, Appl. Catal. B 84 (2008) 176-184.

[25] W. Tang, X. Wu, S. Li, W. Li, Y. Chen, Catal. Commun. 56 (2014) 134-138.

[26] A. Urbutis, S. Kitrys, Cent. Eur. J. Chem. 12 (2014) 492-501.

[27] S. Morales-Torres, F. Carrasco-Marín, A.F. Pérez-Cadenas, F.J. Maldonado-Hódar, Catalysts 5 (2015) 774-799.

[28] M. Tomatis, H.H. Xu, J. He, X.D. Zhang, J. Chem., (2016) Article ID 8324826.

[29] L. Zhang, Y. Peng, J. Zhang, L. Chen, X. Meng, F.-S. Xiao, Chin. J. Catal. 37 (2016) 800-809. 
[30] M.F. Ribeiro, J.M. Silva, S. Brimaud, A.P. Antunes, E.R. Silva, A. Fernandes, P. Magnoux, D.M. Murphy, Appl. Catal. B 70 (2007) 384-392.

[31] J. Cejka, G. Centi, J. Perez-Pariente, W.J. Roth, Catal. Today 179 (2012) 2-15.

[32] B. Ilic, S.G. Wettstein, Micropor. Mesopor. Mater. 239 (2017) 221-234.

[33] E.B.G. Johnson, Sazmal E. Arshad, Appl. Clay Sci. 97-98 (2014) 215-221.

[34] Ch. Baerlocher, L.B. McCusker, D.H. Olson, Atlas of zeolite framework types, Elsevier, $6^{\text {th }}$ revised edition, 2007.

[35] U. Cimenler, B. Joseph, J.N. Kuhn, Appl. Catal. A 505 (2015) 494-500.

[36] P. Boroń, L. Chmielarz, B. Gil, B. Marszałek, S. Dźwigaj, Appl. Catal. B 198 (2016) 457-470.

[37] R. Baran, F. Averseng, D. Wierzbicki, K. Chalupka, J.-M. Krafft, T. Grzybek, S. Dźwigaj, Appl. Catal. A 523 (2016) 332-342.

[38] S. Dzwigaj, J. Janas, J. Mizera, J. Gurgul, R.P. Socha, M. Che, Catal. Lett. 126 (2008) $36-42$.

[39] R. Baran, J-M. Krafft, T. Onfroy, T. Grzybek, S. Dzwigaj, Micropor. Mesopor. Mater. 225 (2016) 515-523.

[40] A. O’Malley, B.K. Hodnett, Catal. Today 54 (1999) 31-38.

[41] A. Rokicińska, P. Natkański, B. Dudek, M. Drozdek, L. Lityńska-Dobrzyńska, P. Kuśtrowski, Appl. Catal. B 195 (2016) 59-68.

[42] Y. Du, Q. Meng, J. Wang, J. Yan, H. Fan, Y. Liu, H. Dai, Micropor. Mesopor. Mater. 162 (2012) 199-206.

[43] A.M. Carrillo, J.G. Carriazo, Appl. Catal. B 164 (2015) 443-452.

[44] S. Zhao, K. Li, S. Jiang, J. Li, Appl. Catal. B 181 (2016) 236-248.

[45] S. Dzwigaj, M. J. Peltre, P. Massiani, A. Davidson, M. Che, T. Sen, S. Sivasanker, Chem. Commun. (1998) 87-88. 
[46] S. Dzwigaj, M. Matsuoka, R. Franck, M. Anpo, M. Che, J. Phys. Chem. B 102 (1998) 6309-6312.

[47] S. Dzwigaj, P. Massiani, A. Davidson, M. Che, J. Mol. Catal. A Chem. 155 (2000) 169182.

[48] S. Dzwigaj, Curr. Opin. Solid State Mater. Sci. 7 (2003) 461-470.

[49] B. Gil, B. Marszałek, A. Micek-Ilnicka, Z. Olejniczak, Top. Catal. 2010 (53) 1340-1348.

[50] J.B. Higgins, R.B. LaPierre, J.L. Schlenker, A.C. Rohrman, J.D. Wood, G.T. Kerr, W.J. Rohrbaugh, Zeolites 8 (1988) 446-452.

[51] S. Dzwigaj, J. Janas, W. Rojek, L. Stievano, F.E. Wagner, F. Averseng, M. Che, Appl. Catal. B 86 (2009) 45-52.

[52] K.A. Chalupka, S. Casale, E. Zurawicz, J. Rynkowski, S Dzwigaj, Micropor. Mesopor. Mater. 211 (2015) 9-18.

[53] A. Szegedi, M. Popova, C. Minchev, J. Mater. Sci. 44 (2009) 6710-6716.

[54] J. Taghavimoghaddam, G.P. Knowles, A.L. Chaffee, J. Mol. Catal. A 358 (2012) 79-88.

[55] A.R. Belambe, R. Oukaci, J.G. Goodwin Jr., J. Catal. 166 (1997) 8-15.

[56] P. Papaefthimiou, T. Ioannides, X.E. Verykios, Appl. Catal. B 13 (1997) 175-184.

[57] Z. Özcelik, G.S. Pozan Soylu, I. Boz, Chem. Eng. J. 155 (2009) 94-100.

\section{Figure captions:}

Fig. 1. X-ray diffraction patterns collected for calcined HAlBEA and SiBEA before and after deposition of Co.

Fig. 2. $\mathrm{N}_{2}$ adsorption-desorption isotherms collected for calcined HAlBEA and SiBEA before and after deposition of Co. 
Fig. 3. Conversion of toluene (A) as well as yields of $\mathrm{CO}_{2}(\mathrm{~B})$ and $\mathrm{CO}(\mathrm{C})$ achieved over HAIBEA and SiBEA and these zeolites doped with 7 wt $\%$ of Co.

Fig. 4. HRTEM and XEDS of SiBEACo5.0 performed at room temperature.

Fig. 5. IR spectra of $\mathrm{NO}$ adsorbed at $-100^{\circ} \mathrm{C}$ on Co-containing SiBEA samples.

Fig. 6. UV-vis diffuse reflectance spectra of SiBEA before and after introduction of various amounts of Co.

Fig. 7. Co 2p XPS spectra and surface composition of Co-containing SiBEA samples.

Fig. 8. $\mathrm{H}_{2}$-TPR profiles of of Co-containing SiBEA samples (as inset the molar \% of Co existing in $\mathrm{Co}_{3} \mathrm{O}_{4}$ phase determined from the $\mathrm{H}_{2}$ consumption of low temperature reduction peak).

Fig. 9. Conversion of toluene achieved over SiBEA before and after introduction of various amounts of Co.

Fig. 10. Changes in toluene conversion observed with time-on-stream at $320{ }^{\circ} \mathrm{C}$ over the Coloaded SiBEA samples.

Fig. 11. Influence of $\mathrm{Co}_{3} \mathrm{O}_{4}$ content on the catalytic activity of the Co-loaded SiBEA samples at $320{ }^{\circ} \mathrm{C}$. 


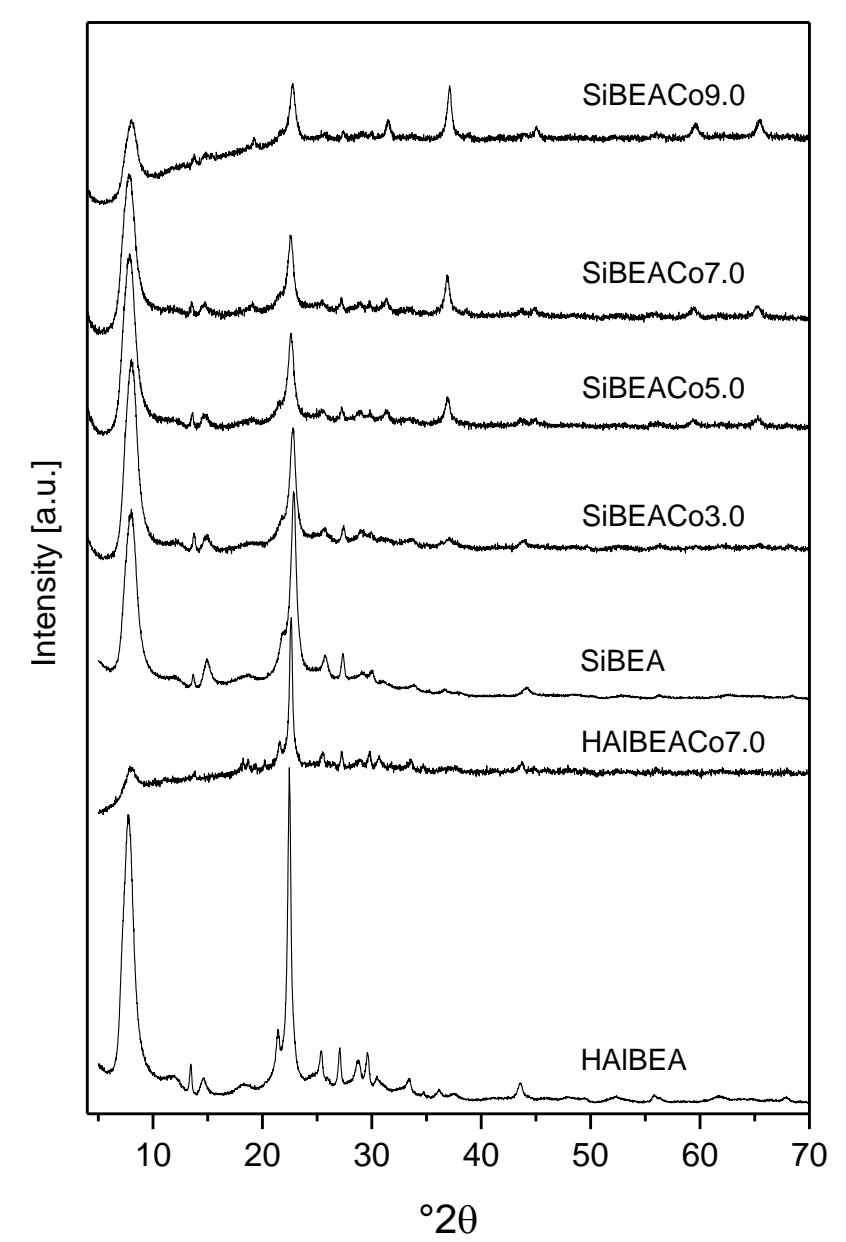

Figure 1. Rokicińska et al. 


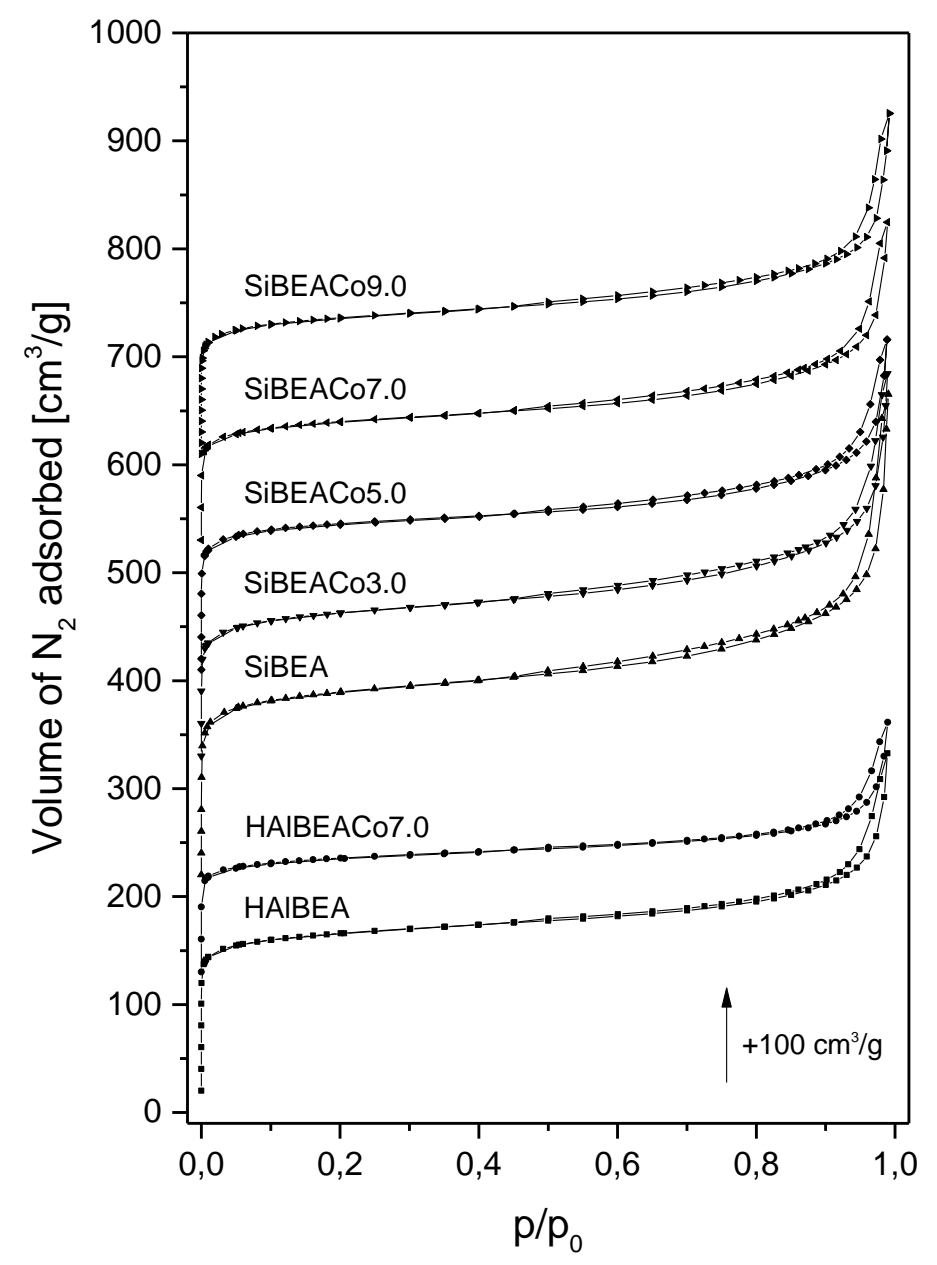

Figure 2. Rokicińska et al. 

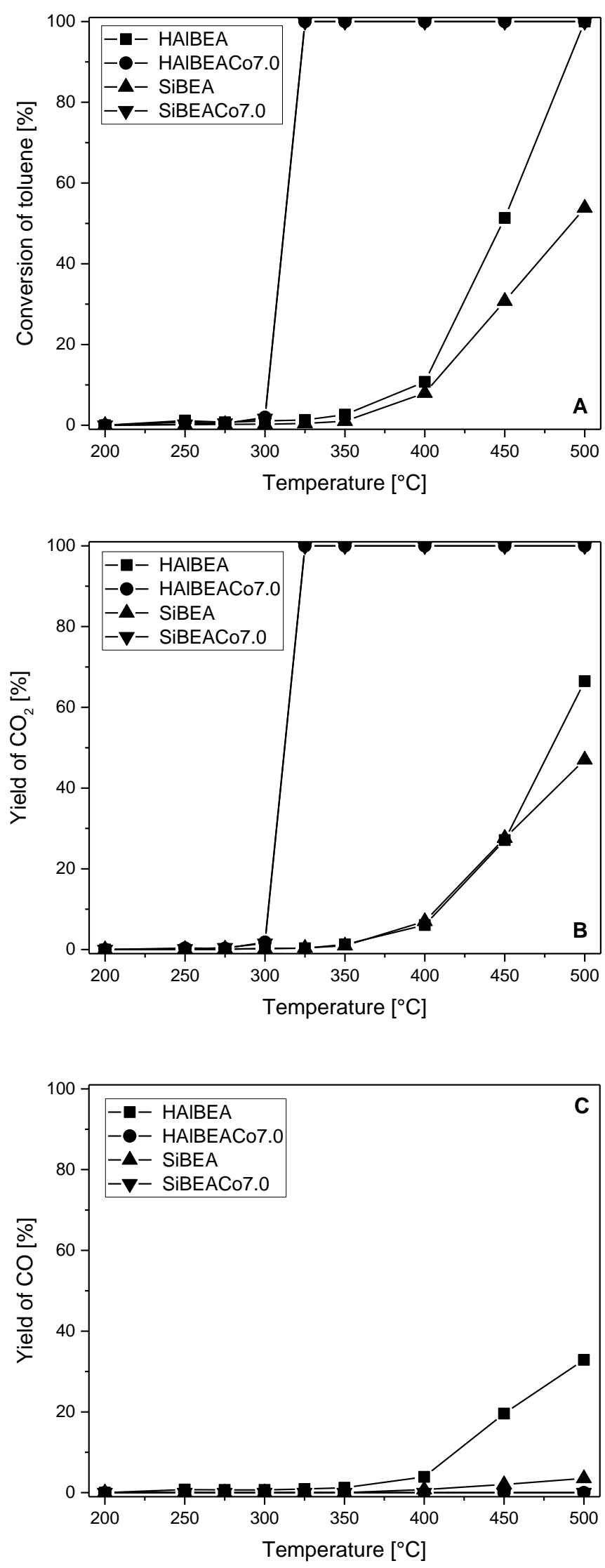

Figure 3. Rokicińska et al. 

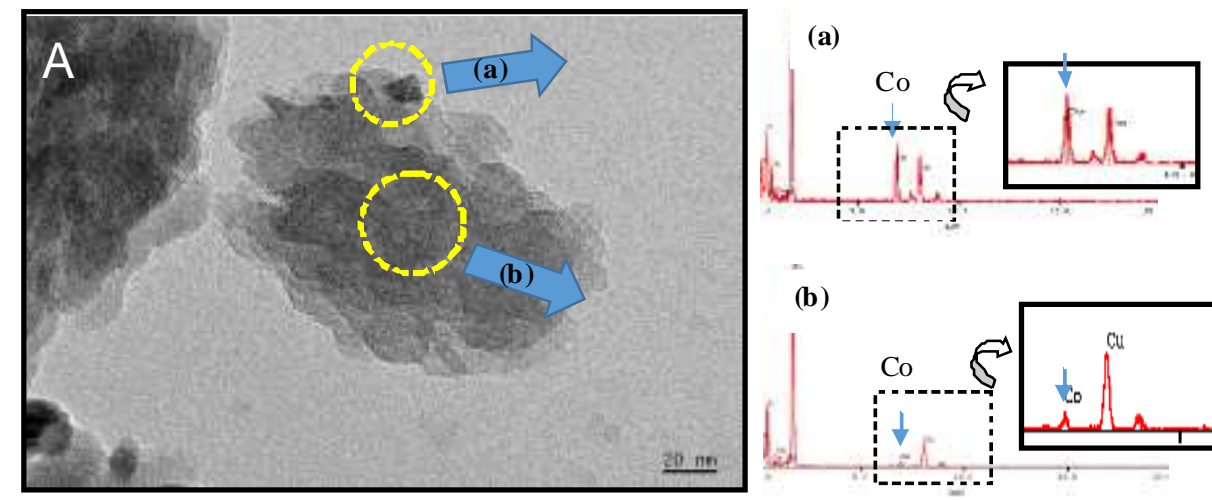

(b)
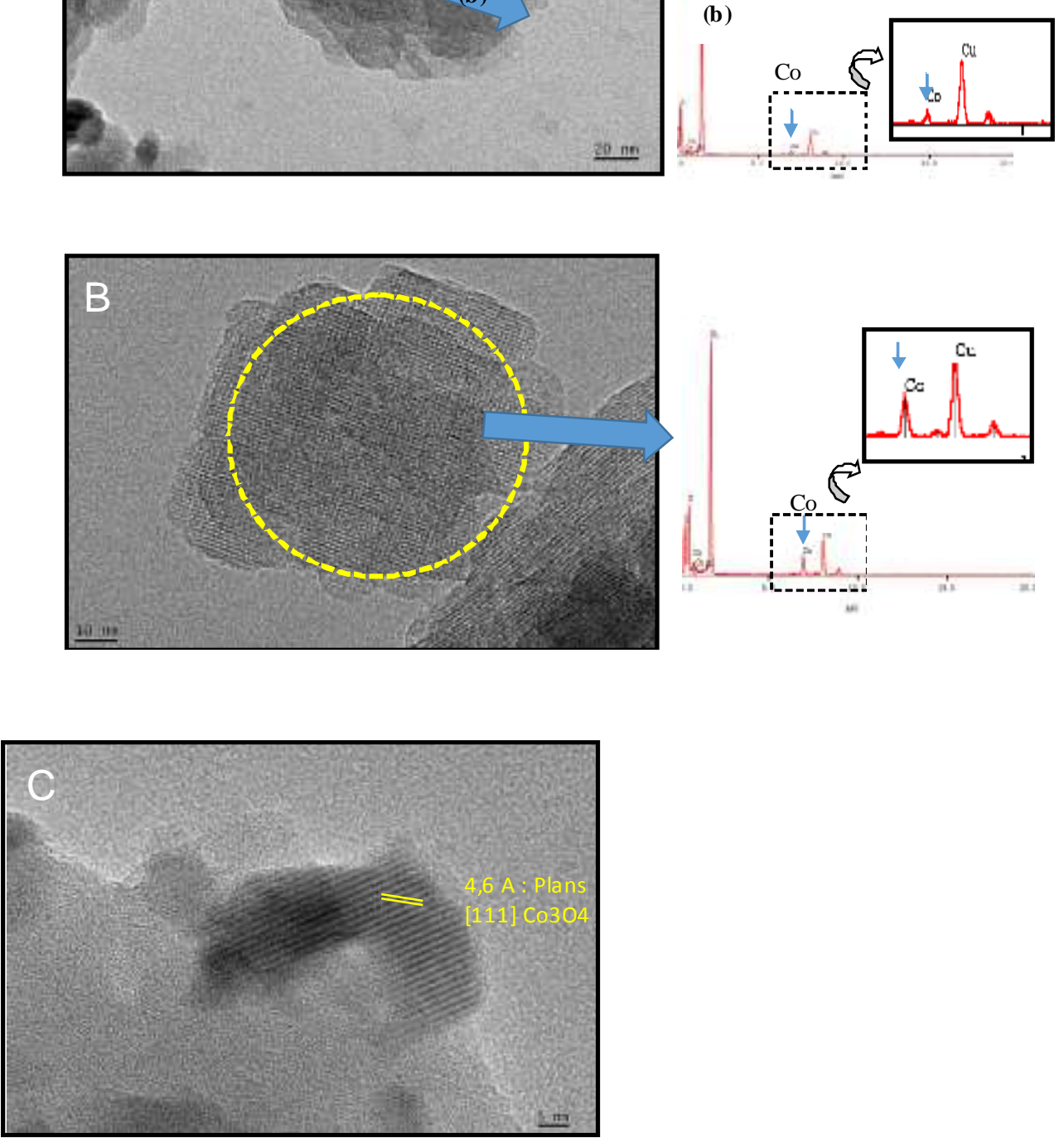

Figure

4.

Rokicińska

et

al. 


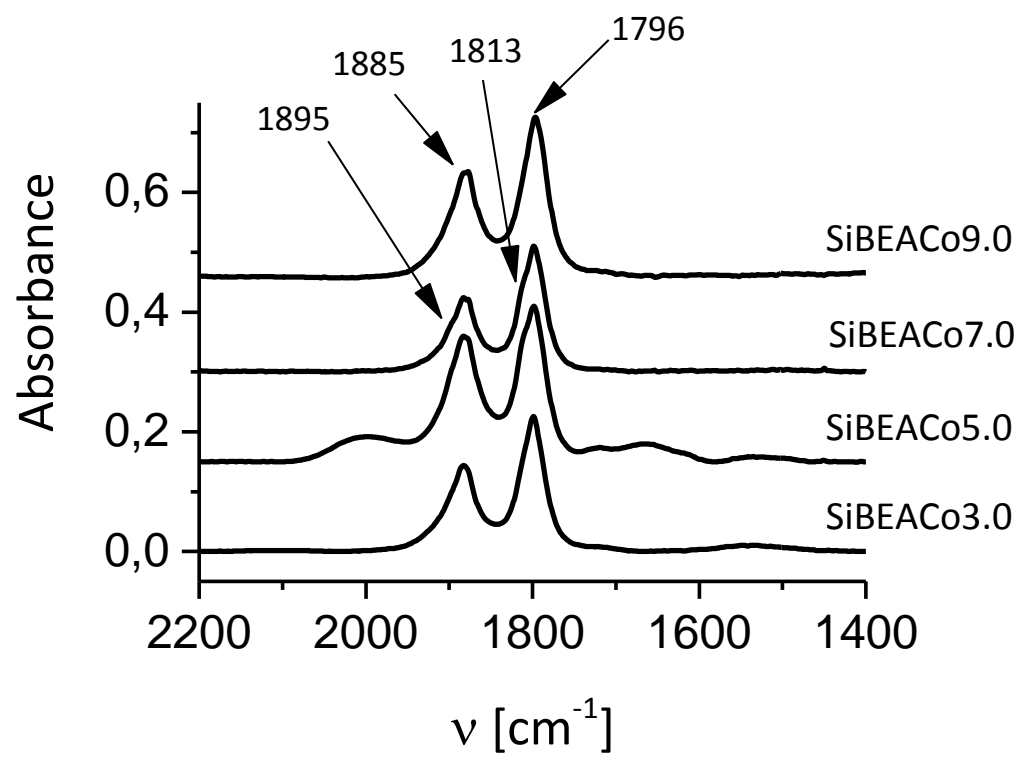

Figure 5. Rokicińska et al. 


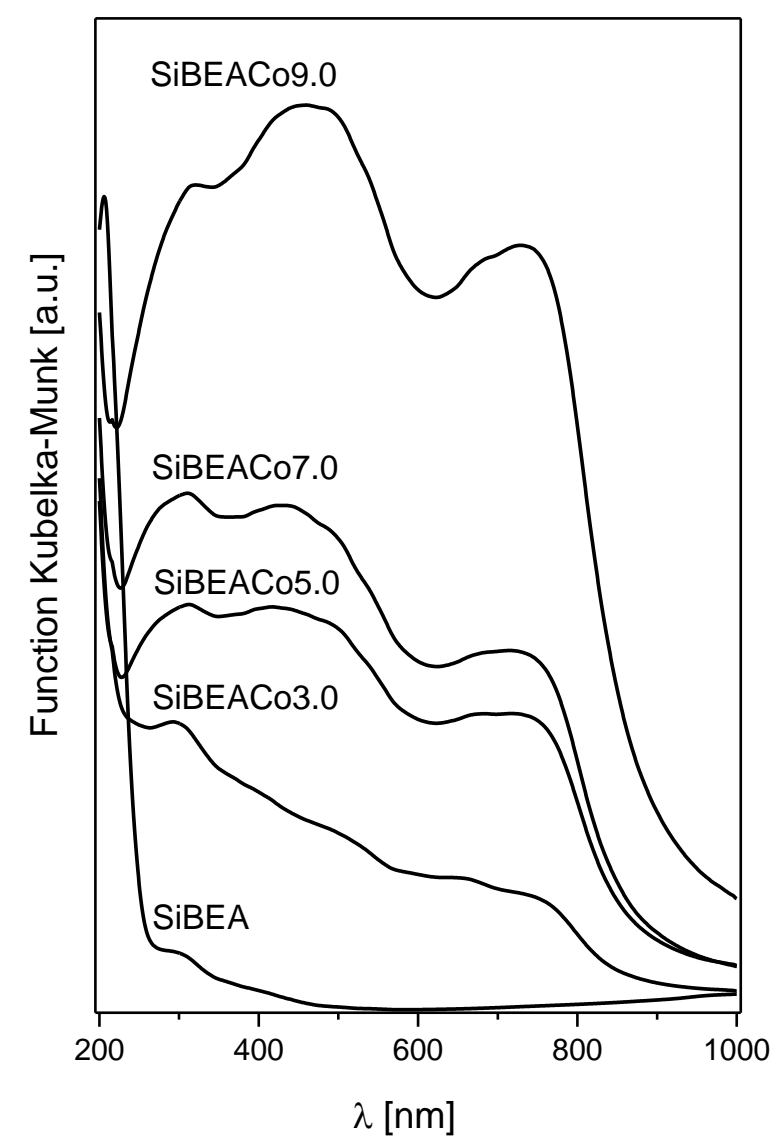

Figure 6. Rokicińska et al. 


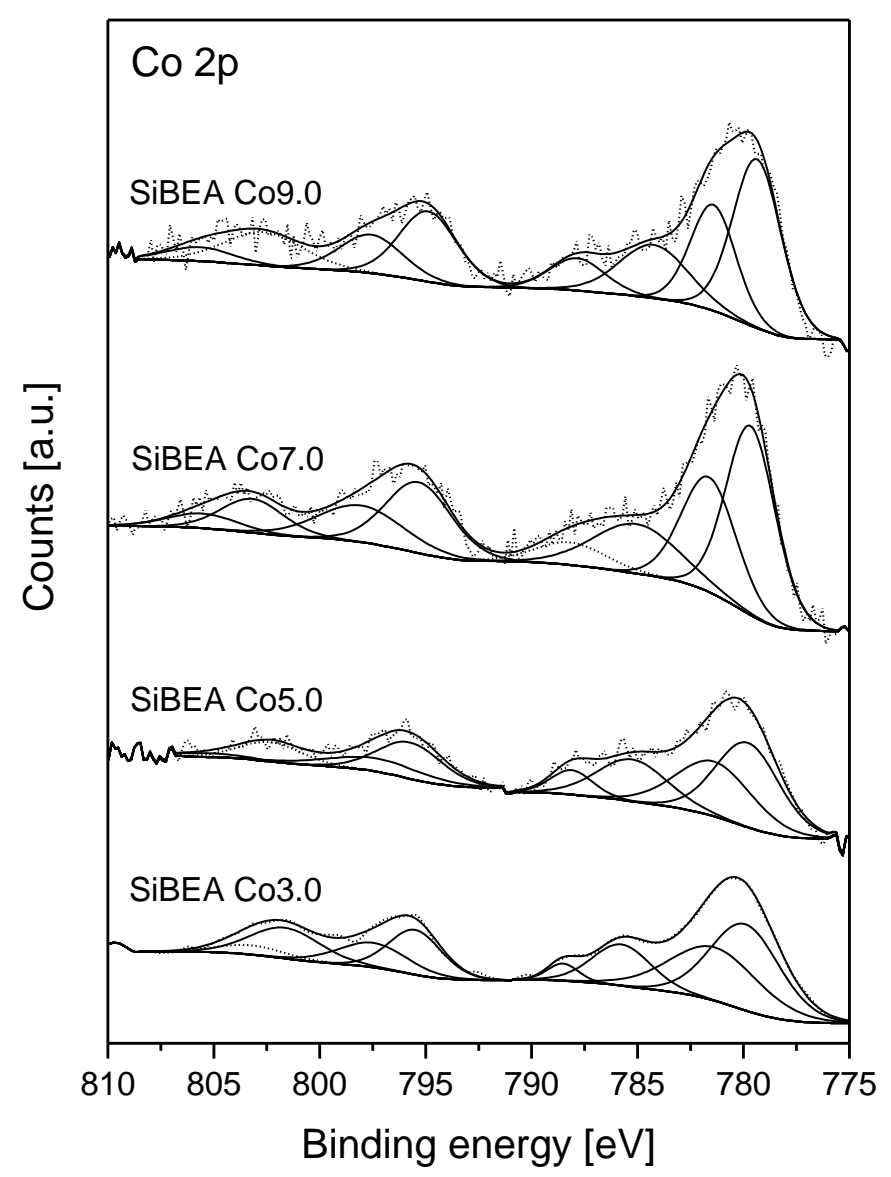

Figure 7. Rokicińska et al. 


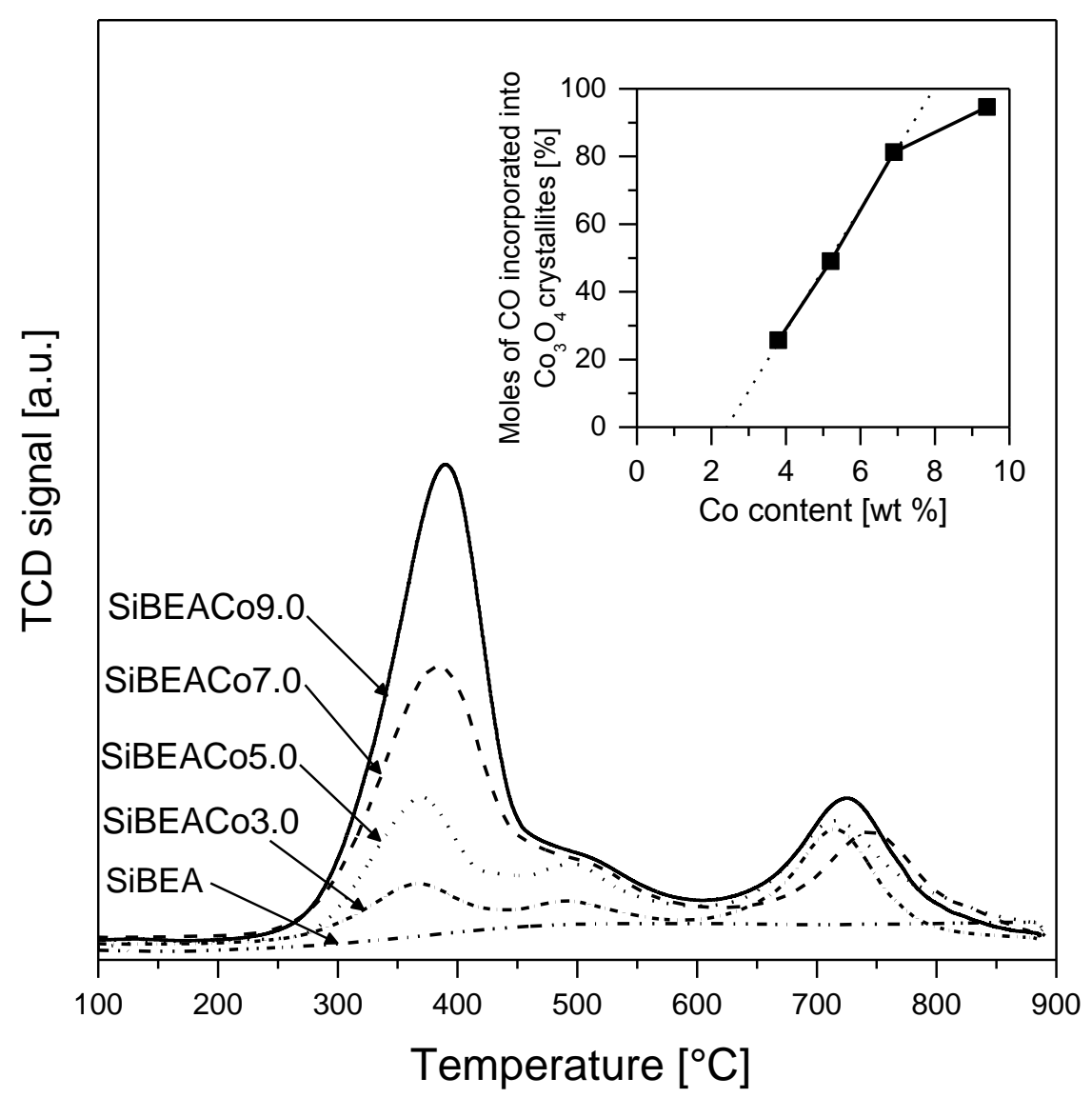

Figure 8. Rokicińska et al. 


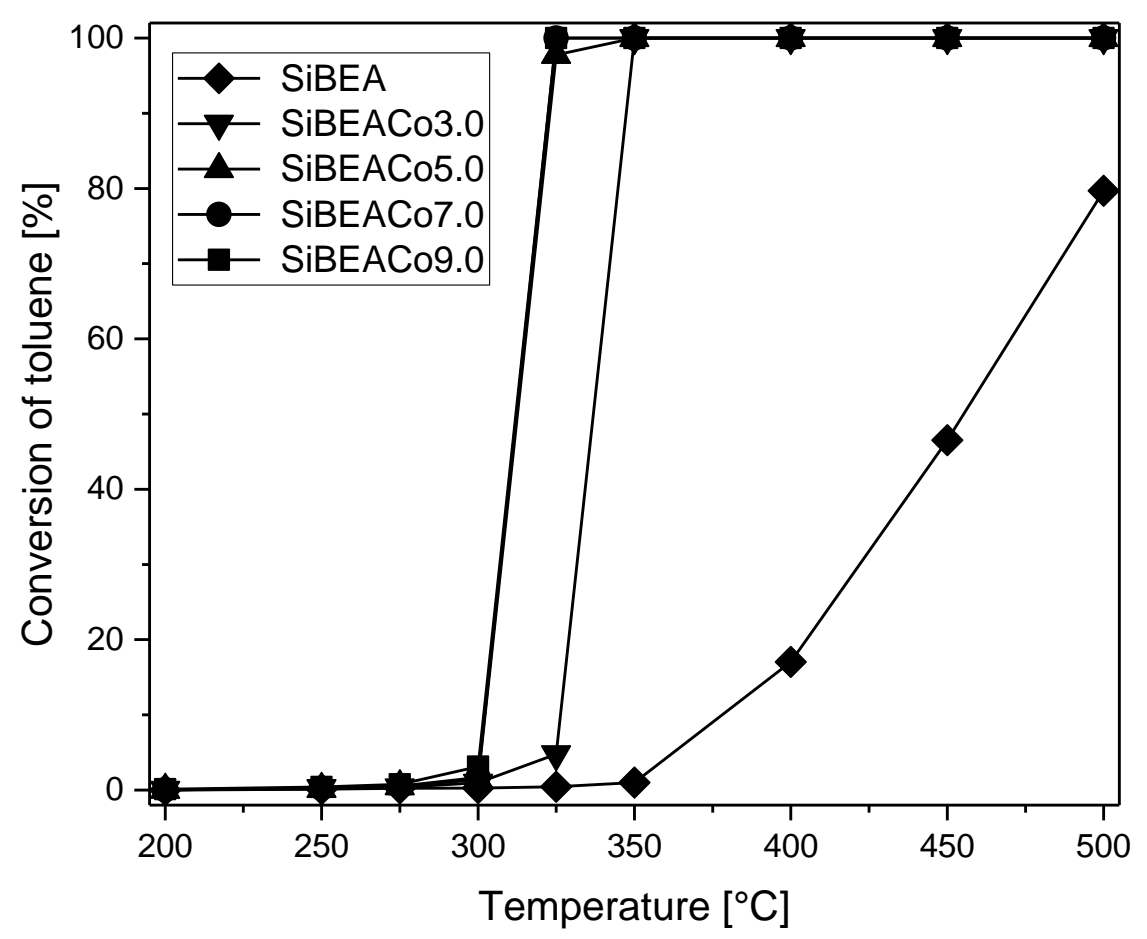

Figure 9. Rokicińska et al. 


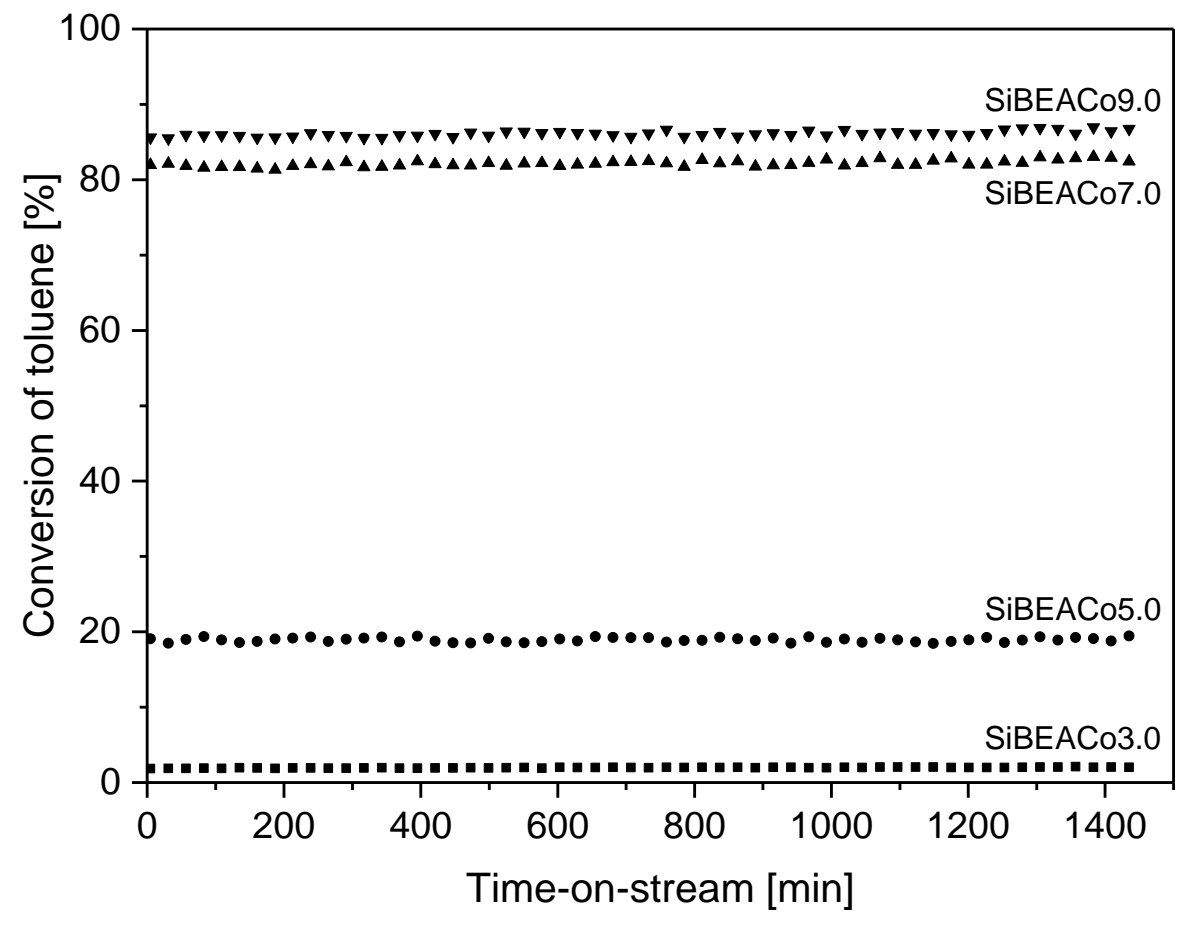

Figure 10. Rokicińska et al. 


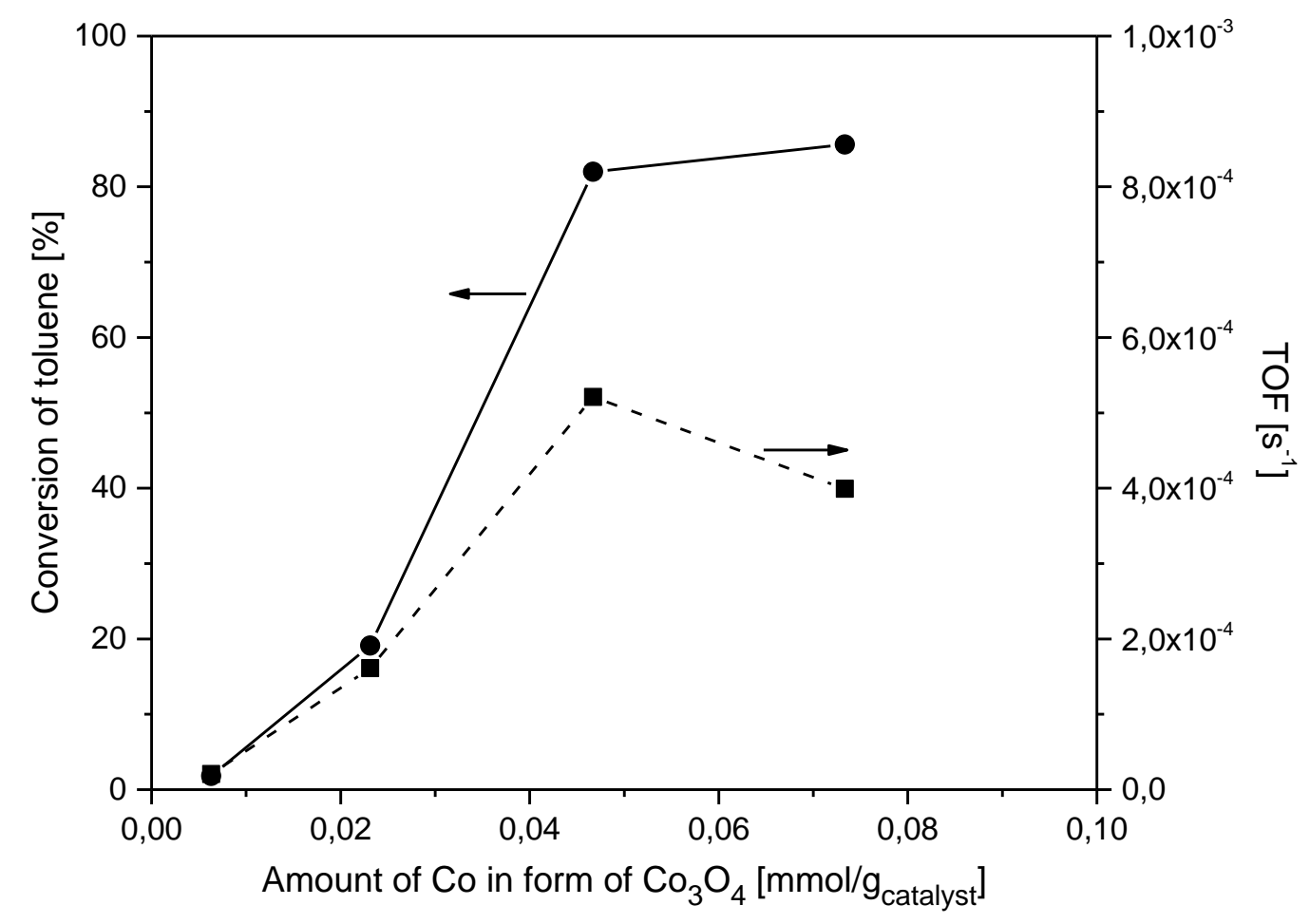

Figure 11. Rokicińska et al. 
Table 1. Composition, textural properties and acidity of the studied BEA zeolite-based materials.

\begin{tabular}{|c|c|c|c|c|c|c|c|c|c|}
\hline \multirow[b]{2}{*}{ Sample } & \multirow[b]{2}{*}{$\begin{array}{l}\text { Co content } \\
\text { [wt \%] }\end{array}$} & \multicolumn{6}{|c|}{ Textural parameters } & \multicolumn{2}{|l|}{ Acidity } \\
\hline & & $\begin{array}{l}\mathrm{S}_{\mathrm{BET}} \\
{\left[\mathrm{m}^{2} / \mathrm{g}\right]}\end{array}$ & $\begin{array}{l}\text { S } \text { Langmuir } \\
{\left[\mathrm{m}^{2} / \mathrm{g}\right]}\end{array}$ & $\begin{array}{l}\text { t-plot } \\
\text { external } \\
\text { surface } \\
\text { area } \\
{\left[\mathrm{m}^{2} / \mathrm{g}\right]}\end{array}$ & $\begin{array}{l}V_{\text {total }} \\
{\left[\mathrm{cm}^{3} / \mathrm{g}\right]}\end{array}$ & $\begin{array}{l}V_{\text {micro }} \\
{\left[\mathrm{cm}^{3} / \mathrm{g}\right]}\end{array}$ & $\begin{array}{l}V_{\text {meso }} \\
{\left[\mathrm{cm}^{3} / \mathrm{g}\right]}\end{array}$ & $\begin{array}{l}\mathrm{PyH}^{+} \\
1545 \mathrm{~cm}^{-1} \\
{[\mu \mathrm{mol} / \mathrm{g}]}\end{array}$ & $\begin{array}{l}\text { PyL } \\
1445- \\
1455 \mathrm{~cm}^{-1} \\
{[\mu \mathrm{mol} / \mathrm{g}]}\end{array}$ \\
\hline HAlBEACo7.0 & 6.7 & 526 & 567 & 42 & 0.405 & 0.191 & 0.151 & 165 & 143 \\
\hline SiBEA & - & 724 & 798 & 88 & 0.720 & 0.251 & 0.273 & 0 & 0 \\
\hline SiBEACo3.0 & 3.8 & 616 & 695 & 80 & 0.595 & 0.213 & 0.257 & 0 & 162 \\
\hline SiBEACo5.0 & 5.2 & 558 & 613 & 57 & 0.489 & 0.198 & 0.208 & 0 & 238 \\
\hline
\end{tabular}


Table 2. Surface composition and XPS parameters of SiBEA zeolites.

\begin{tabular}{|c|c|c|c|c|c|c|c|}
\hline \multirow[t]{2}{*}{ Sample } & \multicolumn{3}{|c|}{$\begin{array}{l}\text { Contribution } \\
\text { [at.\%] }\end{array}$} & \multirow{2}{*}{$\begin{array}{l}\mathrm{Co}^{3+} / \mathrm{Co}^{2+} \\
\text { molar } \\
\text { ratio }\end{array}$} & \multicolumn{2}{|c|}{$\begin{array}{l}\text { Binding energy }[\mathrm{eV}] \\
\text { Co } 2 \mathrm{p}_{3 / 2}\end{array}$} & \multirow{3}{*}{$\begin{array}{l}\text { Co } 2 p_{1 / 2-3 / 2} \\
{[\mathrm{eV}]}\end{array}$} \\
\hline & $\mathrm{O}$ & $\mathrm{Si}$ & $\mathrm{Co}$ & & $\mathrm{Co}^{3+}$ & $\mathrm{Co}^{2+}$ & \\
\hline SiBEA & 65.15 & 34.85 & 0 & - & - & - & \\
\hline SiBEACo3.0 & 63.52 & 34.02 & 2.46 & 1.71 & 779.9 & 781.4 & 16.0 \\
\hline SiBEACo5.0 & 64.03 & 33.58 & 2.40 & 1.77 & 779.8 & 781.4 & 15.9 \\
\hline SiBEACo7.0 & 63.08 & 33.26 & 3.67 & 1.71 & 779.7 & 781.5 & 15.7 \\
\hline SiBEACo9.0 & 57.60 & 39.94 & 2.45 & 1.86 & 779.4 & 781.4 & 15.5 \\
\hline
\end{tabular}

